\title{
The influence of proficiency level on the use and choice of L1/L2 communication strategies used by Iraqi EFL students
}

\author{
Raed Latif Ugla ${ }^{1}$, Mohamad Jafre Zainol Abidin ${ }^{2}$, Mohammed Najim Abdullah ${ }^{3}$ \\ ${ }^{1,3}$ Department of English, Al-Yarmouk University College, Iraq \\ ${ }^{2}$ Universiti Sains Malaysia, Malaysia
}

\begin{tabular}{l}
\hline Article Info \\
\hline Article history: \\
Received Jun 12, 2018 \\
Revised Aug 20, 2018 \\
Accepted Jan 26, 2019 \\
\hline
\end{tabular}

Keywords:

Communication strategies

Foreign language (English)

First language (Arabic)

Second language (English)

Strategic competence

\begin{abstract}
This study aimed to investigate the influence of language proficiency level on the frequency of the use and choice of L1/L2 communication strategies used by Iraqi EFL students. This study was qualitative in nature. The interactive task and speaking task were used to gather data regarding communication strategy use and choice from 52 second and third year English major students. Those participants were divided into two groups; low and high proficient students $(\mathrm{n}=27$ low proficient students and $\mathrm{n}=25$ high proficient students). Taxonomy of communication strategies was adopted to code the communication strategies used by low and high proficient Iraqi EFL students. The results revealed that low proficient students use communication strategies more frequently than high proficient students. Both low and high proficient students used communication strategies other than those included in selected taxonomy. This study showed that low proficient students use L1based strategies more frequently, while high proficient students use L2-based strategies more frequently.
\end{abstract}

Copyright $(0) 2019$ Institute of Advanced Engineering and Science. All rights reserved.

\section{Corresponding Author:}

Mohammed Najim Abdullah, Department of English, Al-Yarmouk University College, Ba'aqubah, Diyala, Iraq. Email: mohamadnajim246@gmail.com

\section{INTRODUCTION}

Recently, it is very important for those who want to learn a foreign language (FL) to communicate orally and effectively. "Nowadays, how to communicate effectively in English as a Foreign Language (EFL) setting has turned into an essential skill next to reading and writing" [1]. To reach this goal, the learners need to develop their communicative competence. According to [2], communicative competence is divided into grammatical, sociolinguistic, discourse, and strategic competence. The speakers use strategic competence to communicate smoothly and fluently through FL. The importance of strategic competence is to work with the strategic knowledge verbally and non-verbally to compensate for failures. For instance: a speaker corrects himself and at the same time strengthens his communication ability.

Oral communication is always known as communication strategies (CSs) [2]. Some speakers use these strategies when they face some difficulties to convey their ideas/ thoughts in the second language (L2) such as "appeal for help," "asking for confirmation," and "asking for clarification." This happens when speakers cannot select or use the appropriate words, idioms, structures, or phrases. These difficulties may be related to their lack of communication competence. Speakers use a number of CSs to remove the difficulties while conveying their thoughts or ideas in speaking task. They use CSs to overcome the problems and difficulties that they may face in delivering the intended idea or expression [3]. However, non-native speakers need to find out the appropriate CSs that enable them to deal with the mismatch in their communicative intentions to get better communication conditions. Communication strategies enable learners 
to stay in a climate of the conversation and provide them with a lot of inputs and opportunities to check and verify their assumptions [4].

Concludes that "Arab learners face many problems in all language skills: listening, speaking, reading and writing". Iraqi EFL students, as in the other Arab countries, have less or limited opportunities to use English outside classroom lessons, which means that there are no other opportunities for learning English through natural interactions [5], [6]. There are many factors that affect the learners' strategic competence. Language proficiency level is one of these factors that affects the use of CSs. Researchers such as [7]-[9] stated that there is no relation between language proficiency level and the use of CSs. Cohen and [10] suggest that the different researchers' opinions about the relationship between CSs and proficiency level might be related to the ways they evaluate the use of CSs. These studies suggested that high proficiency learners able to select the effective CSs better than those of low proficiency level. According to [11], CSs are the most important means for low proficient students to have opportunity to have more language inputs in conversation task.

\section{REVIEW OF RELATED LITERATURE}

The study of CSs started in the 1970. There were a number of studies in this field. [12] Is considered the first one who explained CSs in L2. The definition of CSs varied among researchers such as [13]-[16]. They defined CSs from different perspectives to highlight the importance of these strategies in L2 communication. [14] Defined CS as "a systematic technique practiced by the speakers when faced with difficulty to express the intended meaning." Consequently, [15] defined CSs as "conscious plans to overcome the problems facing an individual to reach the intended meaning of communication process." [8]Paulisse and Schils defined CSs as "strategies used by the speakers when faced with problems in communication and this happen when there is no suitable position of communication forms in the mental dictionary." According to [7], CSs are procedural skills that the speakers employ to compensate lack of sources of interlanguage. Finally, [17] defined CSs as "a systematic attempt by the speakers or the learners to deliver or give the exact meaning that is not proportionate with the rules of the target language."

Non-native speakers cannot master all FL/L2 forms and words. Learners lack in FL may affect their use of CSs when they communicate orally in the target language. Speakers use CSs to help them overcome some of the problems they may face in oral communication due to the lack of their language proficiency. Communication strategies also help them achieve their communication in L2 [8]. Several studies determined the effect of language proficiency level on the use of CSs [17]-[24]. Some studies showed that the students with low language proficiency use CSs more frequently than those with high language proficiency do [17], [18], [25]-[28].

On the other hand, other studies emphasized the relationship between the use of CSs and the language proficiency [19] and [29]. Another researcher [21] argued that low proficiency learners depend more on their first language (L1) knowledge and resort to CSs. Another study [27] showed that the frequency of use of CSs varies among participants depending on their proficiency level which affects the choice of CSs.

More recently, many studies have investigated the effect of proficiency level on the use and choice of CSs [14], [17], and [21]. Consequently, [23] argued that the proficiency level clearly affects the use and the choice of CSs. According to [30], low proficiency speakers tend to rely on L1- based strategies to overcome communication difficulties. On the other hand, he identified that their proficiency level did not influence the number of CSs used.

Additionally, [29] concluded that Turkish EFL learners' proficiency level did not affect the choice of CSs. They stated that high proficiency learners use their body language more effectively, while low proficiency learners rely more on avoidance strategies. Finally, a study of [27] showed that low proficient students used CSs more frequently than those of high proficient students. It also revealed that proficiency level has direct impact on students' frequency use and type of CSs. In contrast, several researchers showed that there were no significant effect of the proficiency level on the use of CSs such as [18], [24], and [26].

\section{METHOD}

\subsection{Research questions}

The present study investigates how Iraqi EFL students with low and high English language proficiency level use and choose CSs while they speak English. It aims to answer the following two questions:

a. How does language proficiency level affect frequency use of CSs in an oral communication?

b. How does language proficiency level affect the choice of CSs in an oral communication?

Int. J. Eval. \& Res. Educ. Vol. 8, No. 1, March 2019: 127 - 137 


\subsection{Research instruments}

To collect data, the current study used two types of instrument namely: interactive task (conversation activity) and speaking task (storytelling). The interactive task was adapted from [31], while the speaking task was adopted from [32]. The researcher used these two types of instruments to put the participants in real speaking interaction and elicit the kinds of CSs they may use during oral test and speaking task.

In this study, the test validity and reliability were checked. To check the internal consistency reliability of the interactive task and the speaking task, second group of 38 participants was tested. Chronbach's alpha formula was used and the reliability coefficient of interactive task was found as (.85) while the reliability coefficient of speaking task was found as (.82), which were statistically excellent. The content validity of these instruments was checked by giving the interactive task and the speaking task to four EFL instructors who were asked to validate the instruments' content with regard to the suitability and relevance of items to the objectives of the current study, the number and arrangement of items, and the suitability of the time allocated to the tests. The four experts unanimously agreed that the tests were valid.

All participants were asked to make a conversation activity about some selected situations in front of other students. They were also asked to tell a story about some selected events such as life story, family story, and last holiday activities. They were asked to draw these events in given drawing sheets and then tell a story in front of other students based on the events included in drawing sheets. The participants were taperecorded while carrying out two tasks: the interactive task (conversation activity) and the speaking task (storytelling).

\subsection{Participants}

The sample of the current study consisted of 52 (22 male and 30 female) second and third year EFL students who study English at department of English language at a private university in Iraq. Those students were native speakers of Arabic. They ranged in age from 19 to 23 years old. Each student completed 8 years of English study prior to entering the college. Those participants were selected because of their availability at particular times, which means that they were not randomly assigned. The researcher divided them into two groups: low and high proficient students. They were divided into two groups based on their achievements in the academic year (2016-2017). The group of students with low proficiency level consisted of 27 students while the group of students with high proficiency level consisted of 25 students.

\section{RESULTS AND DISCUSSION}

Once interactive task and speaking task were audio-recorded and transcribed, the framework by [33] was adopted to code the CSs used by low and high proficient Iraqi EFL students. In order to check the reliability and consistency of the coding, two EFL instructors with Ph.D in applied linguistics were asked by the researcher to code $20 \%$ of data. First of all, the researcher explained the coding procedures to those experts. Then he compared his coding with that of those instructors. The researcher used this coding scheme to find out the extent to which more than two coders agreed on the coding scheme. The researcher and the two instructors independently coded $20 \%$ of transcribed data from the interactive task and speaking task. And then they calculated the coding agreements to check their reliability. The coefficient coding reliability for the interactive task was 0.86 and for the speaking task was 0.89 . These results were acceptable since the intercoder should be ranged from 0.70 to 0.90 [34]. Rabab'ah's taxonomy (Table 1) was selected since it's derived from L1 Arabic language, which was used by Jordanians and L2 the target language, which was the English language and this situation was the same as with Iraqi EFL students (6). A frequency form was designed to classify the CSs that are used by both low and high proficient students during the conversation and storytelling activities. 
Table 1. Rabab'ah's taxonomy of CSs [35]

\begin{tabular}{ll}
\hline Communication Strategies \\
\hline A. & L1-based strategies \\
1. & Literal translation \\
2. $\quad$ Language switch: \\
a. $\quad$ L1 slips and immediate insertion \\
b. $\quad$ L1 appeal for help \\
c. $\quad$ L1-optional meaning strategy
\end{tabular}
Description

Translating literally a lexical item.

E.g. "It is electrical stairs" for" Escalator".

This refers to the use of a word or a phrase from LI to represent in the target language item. This category may be divided into sub-categories according to the reasons

for switching.

Learners insert a word unintentionally -a slip of the tongue. Learners also insert words to complete the intended meaning.

E.g. Nasi (tr: I forgot)... skin scan e: $r(15 \mathrm{sec})$ qiyas $(\operatorname{tr}:$ measure $)(6 \mathrm{sec})$ e: $\mathrm{r}$ ((unintel $3 \mathrm{sec})$ ) em temperature degree?

This refers to when learners use Arabic to appeal for help. The following example is taken from the story-telling task.

E.g. e: $r$ yesterday em ..., the guy? Ghalat? (TR: wrong?) drive er... er drive the [baisklet]

The learners use LI -intended meaning (exact Arabic word) to refer to the object as in the following example. The use of the word ascenseur which was originally French, but has become part of everyday language, is used by the learners. ascenseur (tr: lift) (( the researcher asked "In English? ")) the subject insisted hia ascenseur (tr: it's a lift)

d. L1-retrieval strategies

Learners may realize at a certain time that the item they want to use is there, but they have to retrieve it in some way, so they wait for the term to appear. In the meantime, they use Arabic trying to recall what items they have. The following is a clear example of LI -retrieval strategy. Hathi bisamouha (tr: this is called) $(20 \mathrm{sec})$ to light the room e: $r$ to light the room.

e. L1 ignorance acknowledgement This is used when learners express their ignorance of the target language item required.

E.g. er mush aaref hai (tr: I don't know this).

B. L2-based strategies

1. Avoidance strategies:

a. Message abandonment

b. Topic avoidance

This refers to leaving a message unfinished because of some language difficulty. E.g. The driver didn't do anything to em to prevent er em or to... he didn't do anything.

This refers to reducing the message by avoiding certain language structures or topics considered problematic language-wise, or by leaving out some intended elements as a result of lacking the necessary linguistic resources.

2. Word coinage

3. Circumlocution

This refers to the creation of a non-existent L2 word by applying a supposed L2 rule. E.g. "unmove" in the following utterance. he found this the man who dr who hit them er find him his car is er is... it's unmove

This refers to exemplifying, illustrating, or describing the properties of the target object or action.

E.g. "We use it to make the baby walking in the house easily" to refer to 'baby walker'

4. Self-correction/ Restructuring

This refers to attempts to correct oneself by trying to restructure the utterance to reach the optimal meaning.

E.g. the car was broke... broken.

5. Approximation

Using an alternative lexical item that shares certain semantic features with the target item, or using a generalised TL item.

E.g. The use of 'quicker' in the following example to mean 'faster' The boys em be becau: se they because he is er... very... er quicker... In spee er very speed in driving.

6. Mumbling

7. L2 appeal for help

Swallowing or muttering inaudibly a word (or part of a word) whose correct form the speaker is uncertain about.

E.g. he go er or er ((muttering)) on his bicycle.

This refers to asking for help directly or indirectly. Though the author did not intend to give any help, some subjects appealed for help.

E.g. e: r... I don't know. Electric e: r $(13 \mathrm{sec})$ electric..., ladder? Electric ladder? Electric steps? Step? I don't know.

8. Self-repetition

The learner repeats a word or a string of words immediately after they have been said. E.g. he was very happy because he didn't ca (re) he didn't care for him when he fell.

9. Use of similar-sounding words

This strategy is used to replace a lexical item whose form the speaker is unsure of with an existing or non-existent word which sounds like the target item. E.g. "this is lekstenturel" for "fire extinguisher"

10. Use of all-purpose words

This refers to the use of words like "stuff', "thing", "things" "do" or "make". E.g. the man was trying to fix it (the car). he looked at it and he did the same thing

11. Ignorance acknowledgement This refers to the learner's admission of his lack of the required knowledge when he says that he does not know.

E.g. e: $r$ ern I don't know, tell me.

Int. J. Eval. \& Res. Educ. Vol. 8, No. 1, March 2019: 127 - 137 


\subsection{Results related to research question 1: How does language proficiency level affect frequency use of CSs in an oral communication?}

In the current study, the frequency and the percentage distribution were used as statistical indicators to determine how often Iraqi EFL students with low proficiency level used CSs. The researcher used the formula used by 42 [3] to calculate the frequency of CSs used by low proficient participants. This formula after some justification could be explained as follows:

$$
\text { Frequency of CSs per } 100 \text { words }=\frac{\text { Total frequency of CSs used } \times 100}{\text { Total number of participant's words }}
$$

Table 2 presents only frequency use of CSs by low proficient students. It gave an overview of the number of frequencies of CSs used by low proficient students. It showed the 9 CSs used by participants. These CSs namely: "use of fillers" ( $\mathrm{f}=26 / 4.8 \%)$, "approximation" ( $\mathrm{f}=10 / 1.8 \%)$, "asking for clarification in Arabic" ( $\mathrm{f}=6 / 1.1 \%)$, "self-repetition" ( $\mathrm{f}=4 / 0.7 \%)$, "L1 slips and immediate insertion" ( $\mathrm{f}=4 / 0.7 \%)$, "asking for repetition using L1" ( $\mathrm{f}=1 / 0.1 \%)$, "message replacement" ( $\mathrm{f}=1 / 0.1 \%)$, "L1 appeal for help" ( $\mathrm{f}=1 / 0.1 \%)$, and "feigning understanding" $(\mathrm{f}=1 / 0.1 \%)$.

Low proficient student used "fillers strategy" more frequently. Fillers are phrases, words or empty words such as "you know," "actually," "well," "it is good question," "um," and "uh." Learners use these words to gain time and think about the target word during the oral communication. Although there were 26 instances of "use of fillers strategy," low proficient students used very restricted types of fillers such as "uh" and "um." For example"

Example 1 (Interactive task: conversation activity)

Student 12: I want to invite you to go with me to the Al-Zwarae Park.

Student 5: Uh uh um (fillers) I will come with you,

As it is seen in example 1, student 5 might not be able to remember the target word so that he used fillers (um, uh, um) to gain time to remember the intended word or to arrange his ideas. Low proficient students also used "approximation strategy" more frequently. This strategy enables the leaners to use an alternative lexical term in situation they lack the target words. In the current study, there were 10 instances of "approximation strategy." From the following example 2, the student 41 could not remember the word "younger" or she could not know the target word so that she used the word "small" instead. This word shares some lexical feature with the intended word "younger".

Example 2 (Interactive task: conversation activity)

Student 41: I have three brothers; two of them are secondary students and the small brother (younger) (approximation strategy) is primary student.

Student 22: Uh nice, I have only one brother...

In this study, there were 6 instances of "asking for clarification in Arabic." Using this strategy enables a speaker to use his L1 (Arabic) to ask for clarification since the interlocutor also is native speaker of Arabic. In example 3, the student 31 did not understand what his friend was talking about so that he asked him to explain more using his L1 (Arabic).

Example 3 (Interactive task: conversation activity)

Student 31: Our friend is very sick and he has been sent to the hospital. We have to visit him as soon as possible.

"هل يمكنك ان توضح لي اكثر؟" :

"Hal Youmkinak An Tuwathih Akther?"

Translation: "Could you explain more?"

Example 5: L1 slips and immediate insertion (Interactive task: conversation activity)

Student 9: Hello my dear friend, how are you?

Student 50: Hello, I am fine

Student 9: What do you like me to bring for you?

Student 50: Uh "لاعرف ماذا اقول" (L1 slips and immediate insertion strategy)

Translation: "I do not know what to say"

"L1 appeal for help strategy" allows a speaker to use his own language to ask for help. In this study, there were only 2 instances of using this strategy by low proficient students. In the following example 6 , the student 45 did not how to say the word "waterfalls" in English so that she asked for help using L1 (Arabic).

The influence of proficiency level on the use and choice of L1/L2 ... (Mohammed Najim Abdullah) 
Example 6 (Speaking task: storytelling)

Student 45: I went with my family to the north of Iraq last holiday. Uh we visited many places there especially uh uh "ماذا نسمي الثلالات؟"(L1 appeal for help strategy)

Translation: What do we call the waterfalls?

Low proficient students used "asking for repetition using L1 (Arabic)," "message replacement," "feigning understanding," and "feigning forgetting strategies" less frequently. There was only one example for each strategy. "Asking for repetition using L1 (Arabic) strategy" enables a learner to ask for repetition in his own language when he or she wants to make sure that he or she heard the message correctly. In the following example 7, the student 17 asked the student 3 to repeat the question using his own language (Arabic). This means that the student 17 might not understand the question well so that he asked the student 3 for repetition to be sure that he heard correctly.

Example 7 (Interactive task: conversation activity)

Student 3: Hello

Student 17: Hello

Student 3: Do you want to come with me to the market to buy something?

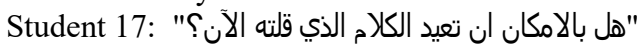

Translation: "Could you repeat what you said just now?"

Subsequently, "using message replacement" enables a learner to replace the message instead of saying the indented one due to insufficient linguistic knowledge. In the following example 8, the student 51 replaced the message. This means that she could not understand the message from the student 36 or she wanted to avoid talking about this subject because of her insufficient linguistic knowledge.

Example 8 (Interactive task: conversation activity)

Student 36: I did not see you for long time.

Student 51: yes, uh um I live in... (Message replacement)

Finally, although a speaker did not understand the message, he was feigning understanding it and continues the conversation. In the example 9, the student 39 feigned that he understands the message of the student 4 and he continued his speaking.

Example 9 (Interactive task: conversation activity)

Student 4: I am so sorry for late. Actually I have another meeting with my boss.

Student 39: I know um um uh I brought the... (Feigning understanding)

Table 2. Frequency use of communication strategies used by low proficient students

\begin{tabular}{lcccc}
\hline \multicolumn{1}{c}{ CSs } & Frequency & Total words used & Percentage of each CS & Ranking \\
& & & 535 & 4.8 \\
Use of fillers & 26 & $=$ & 1.8 & 1 \\
Approximation & 10 & $=$ & 1.1 & 2 \\
Asking for clarification in Arabic & 6 & $=$ & 0.1 & 3 \\
Asking for repetition using L1 (Arabic) & 1 & $=$ & 0.1 & 6 \\
Message replacement & 1 & $=$ & 0.7 & 6 \\
Self-repetition & 4 & $=$ & 0.3 & 4 \\
L1 appeal for help & 2 & $=$ & 0.1 & 5 \\
Feigning understanding & 1 & $=$ & 0.7 & 8 \\
L1 slips and immediate insertion & 4 & $=$ & 9.7 & 4 \\
Total & 55 & & & 9 \\
\hline
\end{tabular}

Table 3 presented frequency use of CSs used by high proficient students during the interactive task and speaking task. This table gave an overview of the number of frequencies of CSs used by high proficient students. It showed the 9 CSs used by participants. These CSs namely: "use of fillers" ( $\mathrm{f}=37 / 6.9 \%$ ), "selfcorrection" ( $\mathrm{f}=4 / 0.7 \%)$, "self-repetition" ( $\mathrm{f}=2 / 0.3 \%)$, and "approximation" ( $\mathrm{f}=1 / 0.1 \%)$.

High proficient student also used "use of fillers strategy" more frequently. They used this kind of strategies to gain time to think about the intended meaning or words. Their usage was different from low proficient students who used only very limited types of fillers such as "uh" and "um." High proficient students used fillers such as "uh," "um," "it is ok," "you know," "well," “er," and "actually.” For example:

Int. J. Eval. \& Res. Educ. Vol. 8, No. 1, March 2019: 127 - 137 
Example 10 (Speaking task: storytelling)

Student 34: I went with my mother to Baghdad to see a doctor there. "Um" "uh" "actually" (fillers strategy) my mother was sick and "you know" (fillers strategy) after that ...

Subsequently, "self-correction strategy" was the second strategy used by high proficient students. In this study there were only 4 instances of using this strategy. Using this strategy enables a speaker to correct himself while speaking in English when he feels that there is something wrong with what he tries to say. As it was seen in the example 11, the student 26 felt that he made mistake and immediately corrected himself by using the target or the correct word.

Example 11 (Speaking task: storytelling)

Student 26: My father is a doctor and my mother is a teacher. She is working in a secondary school...No in an intermediate school... (Self-correction strategy).

Additionally, there were only two instances of using "self-repetition strategy." Using this strategy enables a speaker to repeat what he just said to be sure that his message is conveyed correctly to the interlocutor. For example:

Example 12 (Speaking task: storytelling)

Student 50: I am living with my family in Baladrouse. I have one brother and two sisters. My father death when I was in the primary school "when I was in the primary school" (self-repetition strategy).

Finally, high proficient students used "approximation strategy" less frequently. This strategy enables a speaker to use a word which shares the same features of the intended one. There was only one example of using this strategy by high proficient students. In the following example 13, student 6 used "roster" instead of "pheasant." He used a word which shares enough lexical feature of the target word.

Example 13 (Interactive task: conversation activity)

Student 9: How are you?

Student 6: I am fine

Student 9: I heard that you are good hunter

Student 6: yes, I like hunting

Student 9: What kinds of birds you prefer to hunt?

Student 6: Uh um I prefer the one like a rooster (pheasant) (approximation strategy)

Table 3. Frequency use of communication strategies used by high proficient students

\begin{tabular}{lcccc}
\hline CSs & Frequency & Total words used & Percentage of each CS $100 \%$ & Ranking \\
\hline Use of fillers & 37 & 535 & 6.9 & 1 \\
Approximation & 1 & $=$ & 0.1 & 4 \\
Self-correction & 4 & $=$ & 0.7 & 2 \\
Self-repetition & 2 & $=$ & 0.3 & 3 \\
Total & 44 & $=$ & 8 & 4 \\
\hline
\end{tabular}

\subsection{Results related to research question 2: How does language proficiency level affect the choice of CSs in an oral communication?}

Table 4 presents the kinds of CSs chosen by low and high proficient students during the interactive task and speaking task. This table gave an overview of the number frequencies and percentage of different types of CSs used by those students. It showed that there was a significant difference between low and high proficient students in terms of choosing the kinds of CSs. This significant difference between low and high proficient students was not restricted to $5 \mathrm{CSs}$ included in the Rabab'ah's taxonomy namely: "approximation," "self-correction," "self-repetition," "L1 appeal for help," and "L1 slips and immediate insertion," but also to other 5 strategies namely: "asking for repetition using L1 (Arabic)," "use of fillers," "message replacement," "asking for clarification in Arabic," and "feigning understanding."

On the one hand, low proficient students used 4 CSs which related to their L1 (Arabic) such as asking for clarification in Arabic ( $\mathrm{f}=6 / 1.1 \%$ ), "asking for repetition using L1 (Arabic)" ( $\mathrm{f}=1 / \mathrm{0}$.1\%), "L1 appeal for help" ( $\mathrm{f}=2 / 0.3 \%)$, and "L1 slips and immediate insertion" ( $\mathrm{f}=4 / 0.7 \%)$. On the other hand, high proficient students did no use any CSs which related to L1 (Arabic). They used "use of fillers" ( $\mathrm{f}=37,6.9 \%)$, "self-correction" ( $\mathrm{f}=4,0.7 \%)$, "self-repetition" ( $\mathrm{f}=2,0.3 \%)$, and "approximation" $(\mathrm{f}=1,0.1 \%)$. 
Additionally, low proficient students used 5 CSs which is related to L2 (English) such as "use of fillers" ( $f=26 / 4.8 \%)$, "approximation" ( $f=10 / 1.8 \%)$, "self-repetition" ( $f=4 / 0.7 \%)$, "message replacement" $(\mathrm{f}=1 / 0.1 \%)$, and "feigning understanding" ( $\mathrm{f}=1 / 0.1 \%)$.

As it was shown in Table 4, the proficiency level had direct effects on the choice of CSs. High proficient students focused more on L2 (English) CSs while low proficient students' choice of CSs varied between the L1 (Arabic) and L2 (English) CSs. This difference might be related to their linguistic knowledge which made the high proficient student secure more in speaking task and interactive task than low proficient students.

Table 4. The kinds of CSs chosen by low and high proficient students

\begin{tabular}{|c|c|c|c|c|c|}
\hline $\mathrm{CSs}$ & $\begin{array}{c}\text { Proficiency } \\
\text { level }\end{array}$ & Frequency & Total words used & Percentage of each CS $100 \%$ & Ranking \\
\hline \multirow[t]{2}{*}{ Use of fillers } & $\mathrm{H}$ & 37 & 535 & 6.9 & 1 \\
\hline & $\mathrm{L}$ & 26 & & 4.8 & 4 \\
\hline \multirow[t]{2}{*}{ Approximation } & $\mathrm{H}$ & 1 & $=$ & 0.1 & 2 \\
\hline & $\mathrm{L}$ & 10 & & 1.8 & 2 \\
\hline \multirow[t]{2}{*}{ Self-correction } & $\mathrm{H}$ & 4 & & 0.7 & 2 \\
\hline & $\mathrm{L}$ & 0 & & 0.0 & 0 \\
\hline \multirow{2}{*}{$\begin{array}{l}\text { Asking for clarification } \\
\text { in Arabic }\end{array}$} & $\mathrm{H}$ & 0 & $=$ & 0.0 & 0 \\
\hline & $\mathrm{L}$ & 6 & & 1.1 & 3 \\
\hline \multirow{2}{*}{$\begin{array}{l}\text { Asking for repetition } \\
\text { using L1 (Arabic) }\end{array}$} & $\mathrm{H}$ & 0 & $=$ & 0.0 & 0 \\
\hline & $\mathrm{L}$ & 1 & & 0.1 & 6 \\
\hline \multirow[t]{2}{*}{ Message replacement } & $\mathrm{H}$ & 0 & $=$ & 0.0 & 0 \\
\hline & $\mathrm{L}$ & 1 & & 0.1 & 6 \\
\hline \multirow[t]{2}{*}{ Self-repetition } & $\mathrm{H}$ & 2 & $=$ & 0.3 & 3 \\
\hline & $\mathrm{L}$ & 4 & & 0.7 & 4 \\
\hline \multirow{2}{*}{ L1 appeal for help } & $\mathrm{H}$ & 0 & $=$ & 0.0 & 0 \\
\hline & $\mathrm{L}$ & 2 & & 0.3 & 5 \\
\hline \multirow[t]{2}{*}{ Feigning understanding } & $\mathrm{H}$ & 0 & $=$ & 0.0 & 0 \\
\hline & $\mathrm{L}$ & 1 & & 0.1 & 8 \\
\hline \multirow{4}{*}{$\begin{array}{l}\text { L1 slips and immediate } \\
\text { insertion } \\
\text { Total }\end{array}$} & $\mathrm{H}$ & 0 & $=$ & 0.0 & 0 \\
\hline & $\mathrm{L}$ & 4 & & 0.7 & 4 \\
\hline & $\mathrm{H}$ & 45 & $=$ & 8.1 & 4 \\
\hline & $\mathrm{L}$ & 57 & $=$ & 9.9 & 9 \\
\hline
\end{tabular}

Regarding whether language proficiency level of Iraqi EFL students has an impact on the use of CSs in an oral communication, the results in the interactive task (conversation activity) and speaking task (storytelling) indicated that the participants' proficiency level had direct impact on the use of CSs. These findings were in line with a study of [36], [37] which indicated that language proficiency affects the use and choice of CSs. The statistical analysis done on the interactive task and speaking task results also revealed significant differences between low and high proficient students' use of CSs. This study revealed that low proficient students used L1-based strategies and L2-based strategies variously. It was consistent with a study of [27] who found that the frequency use of CSs varies among participants depending on their proficiency levels.

In general, low proficient students used CSs more frequently than high proficient students. This means that Iraqi EFL low proficient students may encounter many communication problems during the oral communication in the target language, so they tended to use CSs to cope with these difficulties or to solve their communication problems. These results were consistent with a study of [6] which stated that Iraqi low proficient students use CSs more frequently in their oral communication in the target language. In contrast, high proficient students tended less frequently to use CSs to solve their communication problems. This means that high proficient students have the ability to overcome their breakdowns in the target language. This was in line with a study of [35] which indicated that high proficient students use few CSs since they felt confident and their linguistic ability was good.

Proficiency level does not only affect the use of CSs, but also the choice of CSs [23]. Consequently, this study revealed that high proficient students used only L2-based strategies. This means that high proficient students did not rely on their L1 knowledge, but they returned to their L2 knowledge when they have oral communication difficulty. This was in line of a study of [33] which argues that advanced learners use CSs that draw on L1-based strategies less frequently, because their high proficient level assists them or they do not encounter so many difficulties. In contrast, low proficient students did not manage their usage of CSs when they face certain difficulties in the target language. They used "use of fillers" more frequently in their speaking because of their lack of linguistic knowledge.

Int. J. Eval. \& Res. Educ. Vol. 8, No. 1, March 2019: 127 - 137 
High proficient students depended more on their linguistic knowledge and they also tended more to use "use of fillers strategy." Low proficient students do not have enough exposure to the target language, so that they rely on their native language (Arabic) to carry on the intended messages; therefore, they use L1-based strategies namely: literal translation and code switching strategies [37]. Low proficiency learners depend more on their (L1) knowledge and resort to CSs [21].

Additionally, the results of this study also showed that low proficient learners used avoidance strategies such as "approximation" and "self-repetition" more frequently than high proficient learners. Students tend to use avoidance strategies in situations when they face language difficulties [34]. This was in line of a study of [29] which showed that low proficient learners depend more on avoidance strategies.

Finally, the findings revealed that both low and high proficient students use some CSs that were not included in the [33] taxonomy. On the one hand, low proficient students used "asking for repetition using L1 (Arabic)," "message replacement," "asking for clarification in Arabic," and "feigning understanding." This means that low proficient students rely more frequently on their L1 (Arabic) and less frequently on L2 (English) to solve certain oral communication problems or difficulties. It also means that they rely on CSs that already exist in their repertoire of L1 or FL. On the other hand, high proficient used fillers more frequently than low proficient. It means that they know how to deal with their oral communication and rely more on the target language. They also relied on their CSs that already existed in their repertoire of L1 or FL.

It appears that there is no information about any study in Iraq that investigates the effect of language proficiency level on the use and choice of CSs. Most of previous studies in the Arab region adopted taxonomies of CSs conducted by [15], [38]. In the present study, the researcher adopted the CSs included in the [33] taxonomy of CSs.

\section{CONCLUSION}

The findings of this study revealed that Iraqi EFL learners use CSs when they face communication difficulties, but they were not be able to use the suitable one. Low proficient students depended more on their L1 language knowledge and they use L1-based strategies more frequently to deal with their communication problems. This means that they lack linguistic knowledge of the target language. On the other hand, high proficient students used L2-based strategies more frequently to deal with such problems.

In fact, Iraqi EFL students used CSs that already existed in their repertoire of L1 or FL. By enhancing their usage of CSs and alerting them about how CSs are important to get best communicative circumstances in the target language. Teachers should raise their students' awareness towards the importance of CSs in their oral communication and give them the definitions and examples of CSs. They should also encourage their students to use them in their oral communication, so that they learn how to stay safe and convey their message to the interlocutors effectively while they face communication problems or breakdowns in English.

Syllabus designers are also invited to benefit from this study and identify what kinds of CSs that should be included in the EFL syllabus. They have to alert the students on the impact of such CSs in their oral communication and at the same time give them some examples on how to use these strategies in different situations.

Furthermore, this study was carried out at a particular university and included only second and third year low and high proficient students. Therefore, the findings cannot be generalized to other contexts and participants with different proficiency levels (low, intermediate, high). Researchers advise not only to focus on low and high proficient students, but on intermediate proficient students too. They have to carry out researches in different contexts by focusing on different aspects of CSs such as teaching CSs and the effectiveness of CSs in EFL context. They also advise to test how CSs training affect the low, intermediate, and high proficient students' use of CSs.

\section{REFERENCES}

[1] Hua. K., Nor. F., and Jaradat. M., "Communication strategies among EFL students - an examination of frequency of use and types of strategies used," GEMA Online $e^{\mathrm{TM}}$ Journal of Language Studies 831, vol. 12(3), pp. 831-848, 2012.

[2] Canale. M., and Swain. M., "Theoretical bases of communicative approaches to second language teaching and testing," Applied Linguistics, vol. 1, pp. 1-47, 1980.

[3] Lam. W., "Gauging the effects of ESL oral communication strategy teaching: A multi-method approach," E-FLT, vol. 3(2), pp. 142-157, 2006.

[4] Tarone. E., "Speaking in a second language. In E. Hinkel (Ed.)," Handbook of research in second language teaching and Learning. pp. 485-502, 2005.

[5] Mariani. L., "Developing strategic competence: towards autonomy in oral interaction," Perspectives, a Journal of TESOL-Italy - (XX), vol. 1, 1994.

The influence of proficiency level on the use and choice of L1/L2 ... (Mohammed Najim Abdullah) 
[6] Ugla. R.L., Adnan. N. I., and Abdin. M. J., "Study of communication strategies used by Iraqi EFL students," International Journal of Evaluation and Research in Education, vol. 2(1), pp. 44-50, 2013.

[7] Ellis. R., "Classroom second language development," Pergamon, Oxford, 1984.

[8] Poulisse, N., \& Schils. E., "The influence of task- and proficiency-related factors on the use of compensatory strategies: A quantitative analysis," Language Learning, vol. 39(1), pp. 15-48, 1989.

[9] Nakatani. Y., "Developing an oral communication strategy inventory," The modern Language Journal, vol. 90, pp. 151-168, 2006.

[10] Macaro. G., "Language learner strategies: claims and critiques," In: E Macaro, AD Cohen (eds.) Language Learner strategies: 30 years of research and practice. Oxford: Oxford University Press, pp. 9-2819, 2007.

[11] Faucette. P., "A pedagogical perspective on communication strategies: Benefits of training and an analysis of English language teaching materials," Second Language Studies, vol. 19(2), pp. 1-40, 2001.

[12] Selinker. L., "Interlanguage," International Review of Applied Linguistics, vol. 10(3), pp. 209-231, 1972.

[13] Rabab'ah. G., "Second language communication strategies: Definitions, Taxonomies, Date Elicitation Methodology and Teachibility Issues," Educational Resources Centre ERIC. Retrieved from www.eric.ed.gov/ERICWebPortal/detail?accno=ED472698, Apr, 2013.

[14] Corder. S.,"Language-learner language," In Jack C. Richards (Ed.). Understanding Second and Foreign Language Learning. Rowley, Mass: Newbury House, pp. 71-93, 1978.

[15] Faerch. C., and Kasper. G., "Strategies in interlanguage communication," Longman, London, 1983.

[16] Poulisse. N., "Problems and solutions in the classification of compensatory strategies," Second Language Research, vol. 3, pp. 141-153, 1987.

[17] Boxer. D., and D. Cohen. A., "Studying speaking to inform second language learning" Eds. Clevedon, England, 2004.

[18] Dörnyei. Z., and Kormos. J., "Problem solving mechanisms in L2 communication: A psycholinguistic perspective," studies in second language acquisition, vol. 20(3), pp. 349-385, 1998.

[19] Hyde. J., "The identification of communication strategies in the interlanguage of Spanish learners of English," Anglo-American Studies, vol. 2(1), pp. 13-30, 1982.

[20] Bialystok. E., and Frolich. M., "Oral communication strategies for lexical difficulties," Interlanguage Studies Bulletin, vol. 5, pp. 3-30, 1980.

[21] Paribakht. T., "Strategic competence and language proficiency," Applied Linguistics, vol. 6, pp. 132-146, 1985.

[22] Liskin-Gasparro. J., "Circumlocution, communication strategies, and the ACTFL Proficiency Guidelines: an Analysis of Student Discourse," Foreign Language Annals, vol. 29(3), pp. 317-330, 1996.

[23] Dobao. A., "Communication strategies in the interlanguage of Galician students of English: the influence of learner-and task-related factors," Atlantis, vol. 23(1), pp. 41-62, 2001.

[24] Li. R., "The relationship between speaking anxiety and speaking strategies among university students in Taiwan," Master thesis, National Ping Tong University of Education, Ping Tong, Taiwan. Retrieved August 23, 2014, from etd.npue.edu.tw/ETD-db/ETD-search/view_etd?URN=etd-0501107, 2010.

[25] Metcalfe. J., and Noom-Ura. S., "Communication strategy use of high and low proficiency learners of English at a Thai university," LEARN Journal: Language Education and Acquisition Research Network, vol. 6(1), pp. 68-89, 2013.

[26] Rabab'ah. G., "Communication problems facing Arab learners of English: A Personal Perspective," TEFL Web Journal, vol. 2(1), pp. 15-30, 2003.

[27] Chen. S. Q., "A Study of communication strategies in interlanguage production by Chinese EFL learners $I$," Language Learning, vol. 40(2), pp. 155-187, Retrieved November 4, 2015, from http://onlinelibrary.wiley.com/doi/10.1111/j.1467, 1990.

[28] Tuan. H., "Is extroversion-introversion tendency a variable in the choice of strategies in communication?" In: Proceedings of the Eighteenth Conference on English Teaching and Learning in the Republic of China Taipei: Crane, pp. 306-324, 2001.

[29] Uztosun. M., and Erten. I., "The impact of English proficiency on the use of communication strategies: An interaction-based study in Turkish EFL context," Journal of Language and Linguistic Studies, vol. 10(2), pp. 169-182, 2014.

[30] Ting. S., and Phan. G. L., "Adjusting communication strategies to language proficiency," Prospect, vol. 23, pp. 28-36, 2008.

[31] Kongsom. T., "The effects of teaching communication strategies to Thai learners in English," (Doctoral thesis, University Southampton, Southampton, UK), Retrieved July 15, 2015, from https://eprints.soton.ac.uk/69653/1/Tiwaporn_Kongsom_24_11_09.pdf,2009.

[32] British Council., "Activities of speaking. British Council Online Activities," Retrieved February 15, from http://www.teachingenglish.org.uk, 2015.

[33] Rabab'ah. G., "An investigation into the strategic competence of Arab learners of English at Jordanian universities," Ph.D. Dissertation, University of Newcastle upon Tyne.UK, Retrieved June 5, 2014, from https://theses.ncl.ac.uk/dspace/handle/10443/95, 2001.

Int. J. Eval. \& Res. Educ. Vol. 8, No. 1, March 2019: 127 - 137 
[34] Mei. A., and Nathalang. S., "Use of communication strategies by Chinese EFL learners," Chinese Journal of Applied Linguistics, vol. 33, pp. 110-125, 2010.

[35] Abdullah. L., "Communicative tasks and speaking proficiency level on the choice of communication strategies used by Yemen EFL students," Unpublished Ph.D. Thesis. University Sains Malaysia. Malaysia, 2015.

[36] Abunawas. S., "Communication strategies used by Jordanian EFL learners," Canadian Social Science, vol. 8, pp. 178-193, 2012.

[37] Al Alawi. R., "Communication strategies used by Omani EFL students," Pyrex Journal of English and Literature, vol. 2(1), pp. 001-011, 2015.

[38] Dornyei. Z., and Scott. M. L., "Communication strategies in a second language: Definitions and taxonomies," Language learning, vol. 47, pp. 173-210, 1997. 